\title{
Glottic Cancer pT1a TNM Finding v6 and v7
}

National Cancer Institute

\section{Source}

National Cancer Institute. Glottic Cancer pT 1a TNM Finding v6 and v7. NCI Thesaurus.

Code C64674.

Glottic cancer with tumor limited to one vocal cord. (from AJCC 6th and 7th Eds.) 